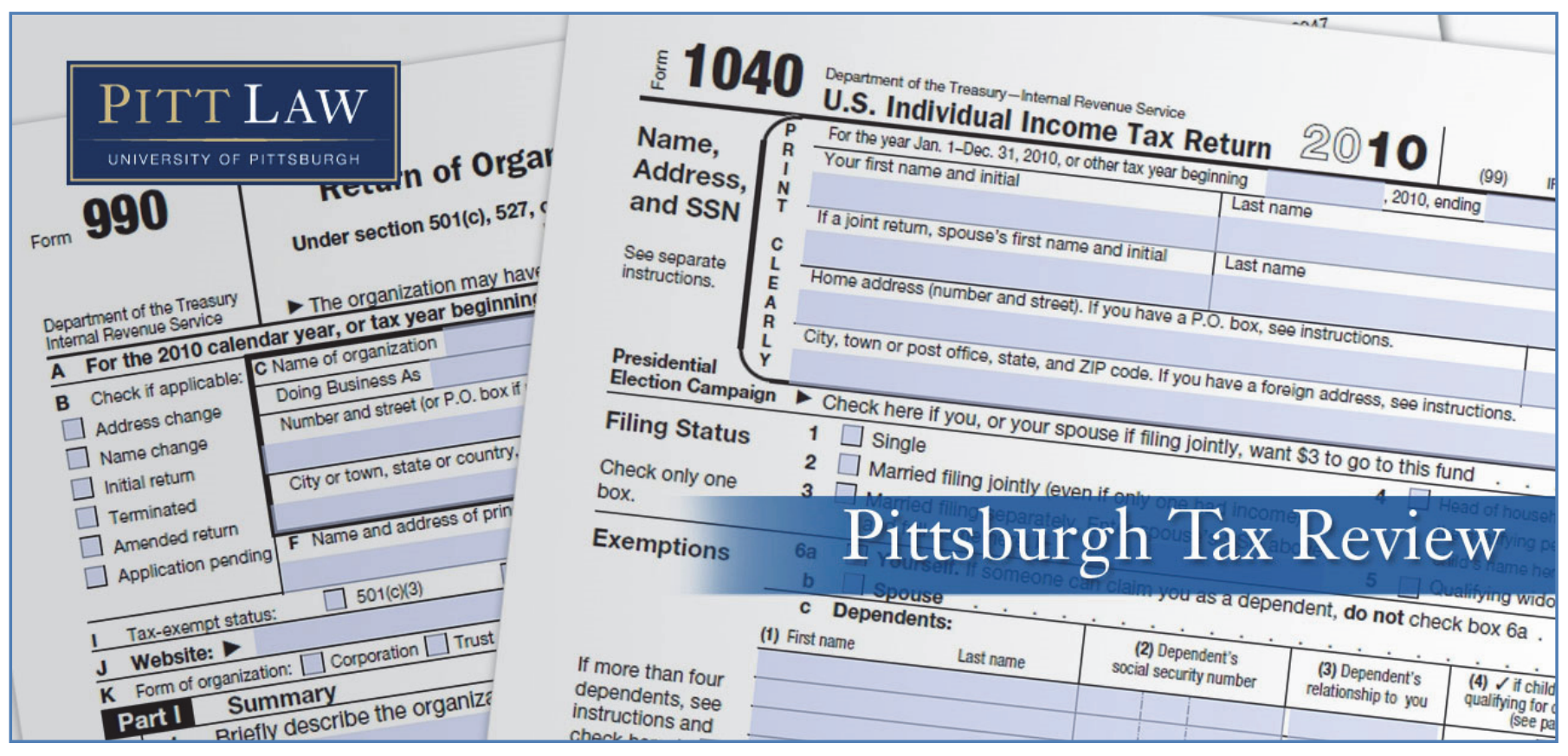

Volume 19 (2021) | ISSN 1932-1821 (print) 1932-1996 (online)

DOI 10.5195/taxreview.2021.149 | http://taxreview.law.pitt.edu

\title{
NOTE
}

\section{EQUITABLE EXPANSION OF THE EARNED INCOME TAX CREDIT TO INCLUDE INCARCERATED INDIVIDUALS}

\section{Danielle Harrington}

\section{(cc) BY-NC-ND}

This work is licensed under a Creative Commons Attribution-Noncommercial-No Derivative Works 3.0 United States License.

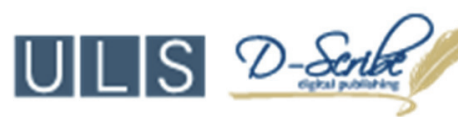

This journal is published by the University Library System of the University of Pittsburgh as part of its D-Scribe Digital Publishing Program, and is cosponsored by the University of Pittsburgh Press. 


\title{
NOTE
}

\section{EQUITABLE EXPANSION OF THE EARNED INCOME TAX CREDIT TO INCLUDE INCARCERATED INDIVIDUALS}

\author{
Danielle Harrington ${ }^{*}$
}

\section{INTRODUCTION}

There are currently 2.3 million incarcerated people in the United States. ${ }^{1}$ Unless a medical professional deems that they have a legitimate medical reason not to, these individuals are required to work while incarcerated. ${ }^{2}$ Currently, prison labor can take a wide variety of forms, with much of the work performed by incarcerated individuals not even taking place within the prison's walls. ${ }^{3}$ Some incarcerated individuals work at the prison itself and do the labor that is needed to keep the prison running by performing essential tasks such as custodial work, "laundry, grounds keeping, [and] food service." Other incarcerated individuals work at businesses owned by the state and produce a variety of goods "that are [later] sold to government agencies." Still other incarcerated individuals work for institutions that are

\footnotetext{
${ }^{*}$ Candidate for JD, 2022, University of Pittsburgh School of Law. I would like to thank Professor Infanti for his feedback and edits and Meera for always being willing to read through my very rough drafts.

${ }^{1}$ Mass Incarceration, ACLU, https://www.aclu.org/issues/smart-justice/mass-incarceration (last visited Aug. 27, 2021).

${ }^{2}$ Whitney Benns, American Slavery, Reinvented, ATL. (Sept. 21, 2015), https://www.theatlantic .com/business/archive/2015/09/prison-labor-in-america/406177/\#: :text=With\%20few\%20xceptions\% 2C\%20inmates $\% 20$ are,hour $\% 2 \mathrm{C} \% 20 \mathrm{if} \% 20$ anything $\% 20$ at $\% 20$ all

${ }^{3}$ Wendy Sawyer, How Much Do Incarcerated People Earn in Each State?, PRISON POL'Y INITIATIVE (Apr. 10, 2017), https://www.prisonpolicy.org/blog/2017/04/10/wages/.

${ }^{4} I d$.

${ }^{5} I d$.
}

Pitt Tax Review | ISSN 1932-1821 (print) 1932-1996 (online) DOI 10.5195/taxreview.2021.149 | http://taxreview.law.pitt.edu 


\section{4 | Pittsburgh Tax Review | Vol. 192021}

not affiliated with the prison or the state at all, such as community organizations, nonprofit organizations, and private businesses. ${ }^{6}$

Individuals who work inside the prison itself tend to make the lowest wages, while those who are able to get a job at businesses owned by the government tend to make some of the highest wages earned by prison laborers. ${ }^{7}$ On average, incarcerated individuals who work for the state make over twice the hourly rate earned by those performing the labor needed to keep the prisons running. ${ }^{8}$ While an incarcerated individual's hourly wage largely depends on the type of job being performed and can vary significantly from state to state, the average incarcerated individual earns somewhere between $\$ 0.14$ and $\$ 1.41$ per hour. ${ }^{9}$ Although these hourly wages fall far below the federal minimum wage, ${ }^{10}$ courts have held that these low wages do not violate federal law because the minimum wage provision of the Fair Labor Standards Act does not apply to incarcerated individuals. ${ }^{11}$ Many states take the additional step of restricting prison laborers to a preset maximum daily wage, further compounding incarcerated individuals' inability to profit from the strenuous work they perform while incarcerated. ${ }^{12}$ In addition to these already low wages, many states also take automatic deductions from incarcerated individuals' wages to pay for things like court fees, victim funds, family support, and savings for expenses that will likely be incurred after release. ${ }^{13}$

${ }^{6}$ Id.; see also Charles Decker, Time to Reckon with Prison Labor, YALE INST. FOR SOC. \& POL'Y STUD., https://isps.yale.edu/news/blog/2013/10/time-to-reckon-with-prison-labor-0\#: :text=Of\%20 course $\% 2 \mathrm{C} \% 20$ prison $\% 20$ labor $\% 20$ is,in $\% 20$ Federal $\% 20$ Prison $\% 20$ Industries $\% 20$ factories (last visited July 23, 2021).

${ }^{7}$ See Sawyer, supra note 3.

${ }^{8} I d$.

${ }^{9}$ Id.

${ }^{10}$ Minimum Wage, U.S. DEP'T OF LAB., https://www.dol.gov/general/topic/wages/minimumwage (last visited Nov. 6, 2021).

${ }^{11}$ Bennett v. Frank, 395 F.3d 409, 409-10 (7th Cir. 2005); see also Danneskjold v. Hausrath, 82 F.3d 37, 39 (2d Cir. 1996).

${ }^{12}$ See Sawyer, supra note 3.

${ }^{13} \mathrm{Id}$.

Pitt Tax Review | ISSN 1932-1821 (print) 1932-1996 (online) DOI 10.5195/taxreview.2021.149 | http://taxreview.law.pitt.edu 
Despite the fact that many aspects of prison labor look vastly different from the work performed by nonincarcerated members of society, incarcerated individuals are subject to the same tax return filing requirements as nonincarcerated individuals. ${ }^{14}$ These returns must include any income that is earned for work done while in prison. ${ }^{15}$ While the tax returns of incarcerated individuals are similar in many respects to those of other lowincome taxpayers, a key difference between the federal income tax returns filed by incarcerated individuals and those filed by other low-income individuals is that incarcerated individuals are barred from claiming the Earned Income Tax Credit on their returns. ${ }^{16}$

\section{THE EARNED INCOME TAX CREDIT}

The Earned Income Tax Credit (EITC) has served as a significant form of federal tax relief for working low-income individuals since the credit's creation in $1975 .{ }^{17}$ The credit "grew out of the 1960s War on Poverty" 18 and was originally introduced to function as a work incentive. ${ }^{19}$ Proponents of the EITC emphasized that the credit would "assist in encouraging people to obtain employment, reducing the unemployment rate, and reducing the welfare rolls." ${ }^{20}$ While the EITC was initially aimed at taxpayers with dependent children, the credit has continually been expanded and is now available to far more taxpayers than it was when it was introduced, including

${ }^{14}$ I.R.C. § 1; see also Brittany Benson, Filing Taxes When a Loved One Is in Prison, H\&R BLOCK (Jan. 13, 2016), https://www.hrblock.com/tax-center/filing/personal-tax-planning/filing-taxes-loved-oneprison/.

${ }^{15}$ I.R.C. $\S 61$; Benson, supra note 14.

${ }^{16}$ I.R.C. $\$ 32(\mathrm{c})(2)(\mathrm{B})(\mathrm{iv})$; Benson, supra note 14.

${ }^{17}$ Rebecca Hasdell et al., Millions of America's Working Poor May Lose Out on Key Anti-Poverty Tax Credit Because of the Pandemic, THE CONVERSATION (Aug. 3, 2020), https://theconversation.com/ millions-of-americas-working-poor-may-lose-out-on-key-anti-poverty-tax-credit-because-of-thepandemic-141846.

${ }^{18}$ Austin Nichols \& Jesse Rothstein, The Earned Income Tax Credit (EITC) 6 (Nat'1 Bureau of Econ. Rsch., Working Paper No. 21211, 2015), https://www.nber.org/papers/w21211.

${ }^{19}$ Id. at 6-7.

${ }^{20}$ Margot L. Crandall-Hollick, Cong. Rsch. Serv., R44825, The Earned Income TaX CREDIT (EITC): A BRIEF LEGISLATIVE HISTORY 4 (2018).

Pitt Tax Review | ISSN 1932-1821 (print) 1932-1996 (online) DOI 10.5195/taxreview.2021.149 | http://taxreview.law.pitt.edu 
taxpayers who do not have children. ${ }^{21}$ Most recently, the Biden administration put forth a proposal that would significantly increase the maximum amount of the credit available to taxpayers without children. ${ }^{22}$

The amount of the EITC varies based on a number of factors, including the amount that the individual makes, the individual's marital status, and the number of children the individual has. ${ }^{23}$ Individuals with children tend to benefit the most from the EITC, and in the years since its inception, the EITC has become the "government's largest cash safety net program for working families with children." ${ }^{24}$ The credit is responsible for lifting over 8.5 million Americans out of poverty in an average year, and it has been referred to as "the largest federal anti-poverty program" provided by the federal government. ${ }^{25}$ The EITC is a fully refundable tax credit, ${ }^{26}$ and even individuals who do not pay any income tax on their earnings are able to receive the EITC. ${ }^{27}$

Significantly, the EITC remains only available to individuals who work, and is phased out for those who earn over a specified amount. ${ }^{28}$ The actual threshold for the EITC phaseout has been amended several times since the credit was first added to the Internal Revenue Code, ${ }^{29}$ and currently ranges between $\$ 21,430$ for single filers with no children and $\$ 57,414$ for married filers with three or more children. ${ }^{30}$ As of 2021 , families with only one child can receive a maximum EITC of $\$ 3,618$, families with three or more children

\footnotetext{
${ }^{21}$ Id.; Nichols \& Rothstein, supra note 18, at 9.

${ }^{22}$ Erica York, Biden Proposals Would Significantly Expand Benefits Administered Through the Tax Code, TAX FOUND. (June 3, 2021), https://taxfoundation.org/biden-budget-biden-child-tax-credit/.

${ }^{23}$ I.R.C. $\S 32(b)$.

${ }^{24}$ Hasdell et al., supra note 17.

${ }^{25}$ Lawrence Zelenak, Redesigning the Earned Income Tax Credit as a Family-Size Adjustment to the Minimum Wage, 57 TAX L. Rev. 301, 301 (2004); Hasdell et al., supra note 17.

${ }^{26}$ Susannah Camic Tahk, The Tax War on Poverty, 56 ARIZ. L. REV. 791, 799 (2014).

${ }^{27}$ Hasdell et al., supra note 17.

${ }^{28}$ Id.; I.R.C. § 32(a)-(b).

${ }^{29}$ Hasdell et al., supra note 17; see also Nichols \& Rothstein, supra note 18.

${ }^{30}$ Earned Income and Earned Income Tax Credit (EITC) Tables, I.R.S., https://www.irs.gov/ credits-deductions/individuals/earned-income-tax-credit/earned-income-and-earned-income-tax-crediteitc-tables (last updated Oct. 8, 2021).
}

Pitt Tax Review | ISSN 1932-1821 (print) 1932-1996 (online) DOI 10.5195/taxreview.2021.149 | http://taxreview.law.pitt.edu 
are eligible to receive a maximum EITC of $\$ 6,728$, and taxpayers with no children can receive a maximum EITC of $\$ 1,502 .{ }^{31}$ While the EITC was introduced to encourage taxpayers to enter the labor force, single parents are the only recipients for whom the credit functions as a true work incentive. ${ }^{32}$ For married couples, the EITC phaseout could actually disincentivize the lower-earning partner from working, as the lower earner's additional income could reduce the amount of the credit that the couple receives. ${ }^{33}$

\section{INCARCERATED INDIVIDUALS ARE CURRENTLY PREVENTED FROM CLAIMING THE EARNED INCOME TAX CREDIT}

Section 32(c)(2)(B)(iv) of the Internal Revenue Code (Code) prohibits incarcerated individuals from claiming the Earned Income Tax Credit. ${ }^{34}$ The section specifies that "no amount received for services provided by an individual while the individual is an inmate at a penal institution shall be taken into account" when calculating the amount of earned income a taxpayer has for purposes of the EITC. ${ }^{35}$ The Tax Court has determined that the language of this section is clear and unambiguous, and the court has continuously upheld incarcerated individuals' exclusion from the credit based on the plain meaning of the statute.

In 1994, Gary James Taylor attempted to claim the EITC while he was incarcerated at the Washington State Reformatory. ${ }^{36}$ In an exceedingly short memorandum opinion, the Tax Court determined that Taylor was precluded

\footnotetext{
${ }^{31}$ What Is the Earned Income Tax Credit?, TAX POL'Y CTR., https://www.taxpolicycenter.org/ briefing-book/what-earned-income-tax-credit (last updated May 2021).

${ }^{32}$ Nichols \& Rothstein, supra note 18, at 19; see also What Is the Earned Income Tax Credit?, supra note 31 .

${ }^{33}$ Nichols \& Rothstein, supra note 18, at 19; Kate Dore, Biden's Boost to the Earned Income Tax Credit May Trigger a 'Marriage Penalty,' CNBC (Aug. 13, 2021), https://www.cnbc.com/2021/08/13/ bidens-earned-income-tax-credit-boost-may-cause-a-marriage-penalty.html; see also What Is the Earned Income Tax Credit?, supra note 31.

${ }^{34}$ I.R.C. $\S 32(\mathrm{c})(2)(\mathrm{B})(\mathrm{iv})$.

${ }^{35} \mathrm{Id}$.

${ }^{36}$ Taylor v. Comm'r, 76 T.C.M. (CCH) 808, 1998 T.C.M. (RIA) ๆ 98,401 (1998).
}

Pitt Tax Review | ISSN 1932-1821 (print) 1932-1996 (online) DOI 10.5195/taxreview.2021.149 | http://taxreview.law.pitt.edu 


\section{8 |Pittsburgh Tax Review | Vol. 192021}

from claiming the EITC based on the language of $\S 32 .{ }^{37}$ Notably, Taylor was not employed in a "typical" prison job. Instead, he was working as a telemarketer for Washington Marketing Group, Inc. while incarcerated. ${ }^{38}$ The Tax Court did not discuss this distinction in the memorandum, and instead simply stated that, because Taylor earned his income while incarcerated, "this income is not earned income for purposes of the credit." 39 As this was the only income Taylor had for the 1994 tax year, he was found to have no earned income for purposes of the EITC. ${ }^{40}$

The Tax Court provided a deeper analysis of this issue when a similar case came before the court several years later. Harold Wilson, who was incarcerated at a Nebraska state prison, attempted to claim a \$335 Earned Income Tax Credit for work he performed while incarcerated. ${ }^{41}$ The court noted that Taylor's employment situation fell outside of the norm for prison labor because Taylor was employed by the private company TEK Industries as a diemaker and earned a significantly higher wage than many other incarcerated individuals, making $\$ 5.50$ per hour. ${ }^{42}$ In the opinion, the Tax Court also acknowledged that some of the money that Taylor earned was taken out of his paycheck and given to a victim's compensation fund, depleting Taylor's already low wages. ${ }^{43}$ Despite the uncertainty posed by Taylor's more unique work arrangement, the Tax Court again held that, as an incarcerated individual, Taylor could not claim the EITC. ${ }^{44}$ In making this determination, the court looked to both the plain language of the statute and the legislative history surrounding the creation of the credit. ${ }^{45}$ Like the statute itself, the legislative history clearly and bluntly speaks to the issue of whether

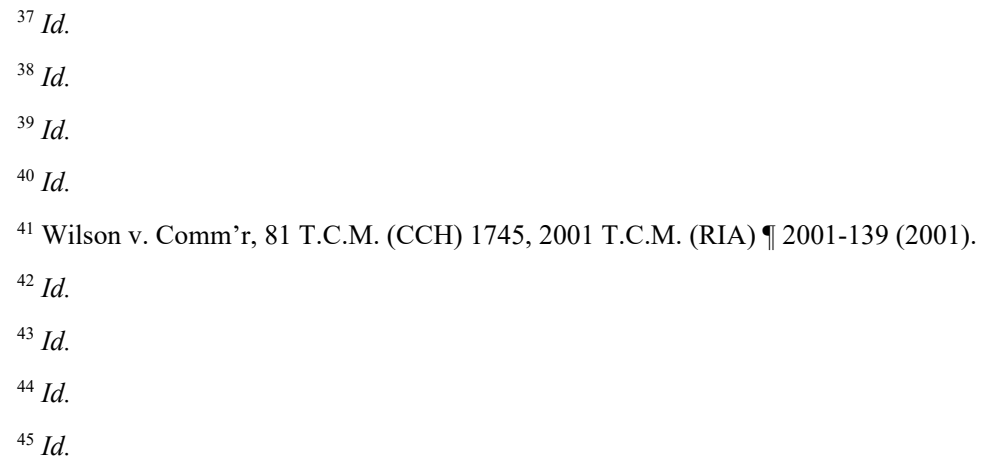

Pitt Tax Review | ISSN 1932-1821 (print) 1932-1996 (online) DOI 10.5195/taxreview.2021.149 | http://taxreview.law.pitt.edu 
incarcerated individuals can claim the EITC. When $\S 32(\mathrm{c})(2)(\mathrm{B})(\mathrm{iv})$ was added to the Code, the reason given for the amendment by legislators was:

The EITC is designed to alleviate poverty and to provide work incentives to lowincome individuals. Because of the compulsory nature of much of the work performed by prison inmates, it does not further the objectives of the EITC to include in earned income for EITC calculations any amounts paid for inmates' services. ${ }^{46}$

The Tax Court found that this explanation bolstered the Commissioner's argument that income earned during incarceration does not count toward the EITC. $^{47}$

In 2004, the Tax Court further solidified its position that the status of incarceration was the most relevant factor in determining whether an individual's earned income is able to count for purposes of the Earned Income Tax Credit, and that an individual's circumstances or specific work situation will not affect the outcome of an individual's dispute with the Internal Revenue Service (IRS). ${ }^{48}$ Delinda Rogers, an incarcerated woman in California, attempted to claim a $\$ 128$ EITC for work that she primarily performed at a site located outside of the prison. ${ }^{49}$ Unlike most prisoners, Rogers was not required to work while incarcerated and instead made the affirmative decision to seek out employment. ${ }^{50}$ Despite this important distinction, the Tax Court found that, like other incarcerated taxpayers, Rogers could not claim the EITC. ${ }^{51}$ The court specified that " $[\mathrm{t}]$ he sole inquiry is whether a taxpayer earned income while he or she was an inmate at a penal institution; other factors, such as the status of the payor as either a public or private entity, are irrelevant." 52

Most recently, in 2017, the Tax Court once again determined that an inmate who worked while incarcerated was not entitled to claim the Earned

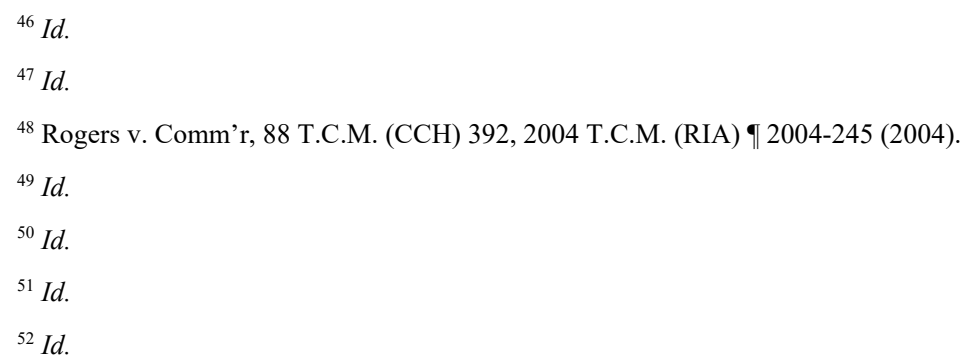

Pitt Tax Review | ISSN 1932-1821 (print) 1932-1996 (online) DOI 10.5195/taxreview.2021.149 | http://taxreview.law.pitt.edu 


\section{0 | Pittsburgh Tax Review | Vol. 192021}

Income Tax Credit on their return. ${ }^{53}$ In 2015, Kevin Skagg, an inmate at the Kansas Department of Corrections, earned only $\$ 2,921$ in income, sixty-two dollars of which was withheld by his employer. ${ }^{54}$ Skagg attempted to claim the EITC on his tax return in the amount of $\$ 224 .{ }^{55}$ At the time that he earned the income at issue, Skagg was not being held at the prison itself; instead, he was a patient at Larned State Hospital, a state security hospital affiliated with the prison. ${ }^{56}$ After reviewing his return, the IRS determined that Skagg could not claim the EITC because he was incarcerated for the entirety of the taxable year. ${ }^{57}$ The Tax Court upheld the IRS's determination based on the text of $\S 32$ (c)(2)(B)(iv). ${ }^{58}$ The court also cited its previous determination in Rogers $v$. Commissioner that incarcerated individuals cannot claim the EITC regardless of whether they worked at the prison itself or offsite..$^{59}$ Once again, the status of incarceration was the determining factor in whether the taxpayer was able to claim the EITC, and other considerations such as the location where the work was performed, the identity of the employer, and the individual's wages did not play a role in the court's holding. ${ }^{60}$

\section{DENYING INCARCERATED INDIVIDUALS THE TAX RELIEF OFFERED BY THE EARNED INCOME TAX CREDIT IS INEQUITABLE}

While there is not extensive legislative history detailing the drafters' full intention for the future of the credit, ${ }^{61}$ it is clear that the Earned Income Tax Credit was designed to provide very low-income individuals who work with additional cash support after they file their tax returns. Incarcerated individuals' inability to claim the benefits of the EITC is a vestige of the

\footnotetext{
${ }^{53}$ Skaggs v. Comm'r, 148 T.C. 367 (2017).

${ }^{54}$ Id. at 368 .

${ }^{55} \mathrm{Id}$.

${ }^{56} \mathrm{Id}$.

${ }^{57} \mathrm{Id}$.

${ }^{58} I d$. at 369.

${ }^{59} \mathrm{Id}$. at 371.

${ }^{60} \mathrm{Id}$.

${ }^{61}$ Zelenak, supra note 25, at 301.
}

Pitt Tax Review | ISSN 1932-1821 (print) 1932-1996 (online) DOI 10.5195/taxreview.2021.149 | http://taxreview.law.pitt.edu 
credit's initial purpose of serving as a work incentive. ${ }^{62}$ The limited legislative history reveals that because incarcerated individuals are already forced to perform labor, they do not need to be encouraged to enter the workforce in the same way that other low-income taxpayers might need to be. ${ }^{63}$ In the years since its creation, however, the EITC has evolved into one of the largest antipoverty programs in the United States. ${ }^{64}$ While the exclusion of incarcerated individuals might have been logical at the inception of the EITC, the credit's continued expansion and the important role that the credit plays in supporting low-income individual ${ }^{65}$ has made the exclusion of incarcerated individuals an arbitrary holdover rather than a rational policy decision.

There are significant policy reasons to allow incarcerated individuals to claim the EITC. The labor performed by incarcerated individuals helps to operate the prisons that incarcerated individuals are housed in and provides inexpensive labor to both the state and private entities. ${ }^{66}$ Incarcerated individuals make well below any mandated state or federal minimum wage and, as a result, earn significantly less than nonincarcerated low-income workers who are currently able to claim the EITC. ${ }^{67}$ Mandatory deductions for items such as court fees and victim's compensation funds routinely slash incarcerated individuals' already low earnings. ${ }^{68}$

${ }^{62}$ Wilson v. Comm'r, 81 T.C.M. (CCH) 1745, 2001 T.C.M. (RIA) ๆ 2001-139 (2001).

${ }^{63} \mathrm{Id}$.

${ }^{64}$ Earned Income Tax Credit \& Other Refundable Credits, I.R.S. (Jan. 19, 2021), https://www.eitc .irs.gov/eitc-central/about-eitc/about-eitc; EITC (Earned Income Tax Credit), UNIV. OF N.C. SCH. OF GOV'T, https://ncimpact.sog.unc.edu/our-work/economy/eitc/ (last visited Aug. 26, 2021); see also STAFF OF H.R. COMm. ON THE Budget, 115Th CONG., THE EARned Income TaX CRedit Boosts Work, REDUCES POVERTY, AND PROVIDES OTHER BENEFITS FOR WORKING AMERICANS (Comm. Print 2018).

${ }^{65}$ Zelenak, supra note 25, at 301; see Hasdell et al., supra note 17.

${ }^{66}$ Sawyer, supra note 3 ; see also Decker, supra note 6.

${ }^{67}$ See Bennett v. Frank, 395 F.3d 409, 409-10 (7th Cir. 2005); see also Danneskjold v. Hausrath, 82 F.3d 37, 39 (2d Cir. 1996).

${ }^{68}$ Sawyer, supra note 3.

Pitt Tax Review | ISSN 1932-1821 (print) 1932-1996 (online) DOI 10.5195/taxreview.2021.149 | http://taxreview.law.pitt.edu 
In addition to the extremely low wages earned by those who are incarcerated, low-income individuals are overrepresented in U.S. prisons. ${ }^{69}$ Approximately one-half million people are currently imprisoned solely because they are unable to pay to be released from prison. ${ }^{70}$ The prevalence of impoverished individuals in the prison population means that people who are being paid far below the minimum wage face the additional barrier of not having a safety net capable of providing them with money from outside of prison. Because many inmates are often not able to receive additional support from loved ones, every dollar that they make is significant to them.

While many people assume that incarcerated individuals have no need for money while they are in prison, incarcerated individuals have a high cost of living relative to their overall earnings. Although prisons provide for basic needs such as food and shelter, incarcerated individuals are required to pay for many other essential items. ${ }^{71}$ Some basic toiletries such as shampoo, conditioner, toothpaste, and lotion can only be obtained at the commissary. ${ }^{72}$ Beyond the basic daily needs of incarcerated people, contact with family and friends and hobbies have become monetized as prisons have grown and evolved. Phone calls between incarcerated individuals and their family and friends can be costly, and in some states a fifteen-minute phone call can cost the individual and their family over twenty dollars. ${ }^{73}$ This problem has increased dramatically in recent years, as prisons were forced to stop inperson visits with family and friends at the start of the COVID-19 pandemic. ${ }^{74}$ This led to the advent of video calling in place of in-person

${ }^{69}$ Tara O’Neill Hayes \& Margaret Barnhorst, Incarceration and Poverty in the United States, AM. ACTION F. (June 30, 2020), https://www.americanactionforum.org/research/incarceration-and-povertyin-the-united-states/\#: :text=The $\% 20$ United $\% 20$ States $\% 20$ is\%20currently,to\%20pay $\% 20$ for $\% 20$ their $\%$ 20release.

${ }^{70} I d$.

${ }^{71}$ See Sawyer, supra note 3.

${ }^{72}$ See Brian Wood, Behind Bars: Low Wages for Prisoners Makes Inmates Appreciate the Little Things, STANDARD-EXAM'R (Nov. 14, 2016), https://www.standard.net/opinion/2016/nov/14/behindbars-low-wages-for-prisoners-makes-inmates-appreciate-the-little-things/; see also Print Products, CANTEEN SERVS., http://www.doccanteen.com/index.html\#printable (last visited July 22, 2021).

${ }^{73}$ Tyler Kendall, Why Are Jail Phone Calls So Expensive?, CBS News (Oct. 13, 2020, 7:07 PM), https://www.cbsnews.com/news/why-are-jail-phone-calls-so-expensive/.

${ }^{74}$ See Charlie Dietch, Fahrenheit 412: New Rule Bans Allegheny County Jail Inmates from Receiving Books, PITTSBURGH CURRENT (Nov. 18, 2020), https://www.pittsburghcurrent.com/fahrenheit-

Pitt Tax Review | ISSN 1932-1821 (print) 1932-1996 (online)

DOI 10.5195/taxreview.2021.149 | http://taxreview.law.pitt.edu 
visits, which can be extremely costly for incarcerated individuals. ${ }^{75}$ In Pennsylvania, a video call with family can cost up to $\$ 7.50,{ }^{76}$ which is nearly five times the highest average hourly rate the majority of incarcerated individuals can earn. ${ }^{77}$

Even recreational activities within the prisons that many members of the public may assume are free have become costly for incarcerated individuals. While prisons often provide free access to many reading materials, the introduction of tablets into the prison system has led to additional costs to access e-books, with incarcerated individuals often being charged per minute they spend reading a book. ${ }^{78}$ Public outcry has led some states to abandon the practice of charging incarcerated individuals for reading materials, but it has been estimated that it could cost up to twenty dollars for a person to read a shorter novel such as $1984 .^{79}$ Being charged per minute spent reading is especially troubling for incarcerated individuals with learning disabilities or vision problems, who will likely pay higher rates than other individuals to read the same material due to the extra time it takes them to read. ${ }^{80}$ If the EITC is truly meant to serve as one of the country's most significant antipoverty programs, ${ }^{81}$ the EITC should be available to society's lowestearning workers who have extremely high costs of daily living relative to their earning capacity.

412-new-rule-bans-allegheny-county-jail-inmates-from-receiving-books-reading-limited-to-214-selecte-books/.

${ }^{75} \mathrm{Id}$.

${ }^{76} \mathrm{Id}$.

${ }^{77}$ See Sawyer, supra note 3; see also Decker, supra note 6.

78 Eldon Ray James, Prisoners Pay to Read, Am. LiBrs. (May 22, 2020), https:// americanlibrariesmagazine.org/blogs/the-scoop/prisoners-pay-to-read-prison-tablets/\#: :text=Until\%20 inmates $\% 20$ realize $\% 20$ the $\% 20$ company, autobiography $\% 20$ they $\% 20$ attempt $\% 20$ to $\% 20$ read.

${ }^{79} \mathrm{Id}$.

${ }^{80} \mathrm{Id}$.

${ }^{81}$ Earned Income Tax Credit \& Other Refundable Credits, supra note 64; EITC (Earned Income Tax Credit), supra note 64; see also STAFF OF H.R. COMM. ON THE BUDGET, supra note 64.

Pitt Tax Review | ISSN 1932-1821 (print) 1932-1996 (online) DOI 10.5195/taxreview.2021.149 | http://taxreview.law.pitt.edu 


\section{4 | Pittsburgh Tax Review | Vol. 192021}

In addition to the high costs of daily living faced by incarcerated individuals, a staggering number of incarcerated individuals have children. ${ }^{82}$ While an exact figure is not available, it has been estimated that between fifty and seventy-five percent of incarcerated individuals have a child who is a minor. ${ }^{83}$ Having a dependent child is typically a significant factor in the calculation of the EITC ${ }^{84}$ and often leads to individuals claiming a much higher EITC on their returns. ${ }^{85}$ As the EITC was originally available only to working parents, incarcerated parents' exclusion from the credit is a significant failing. ${ }^{86}$

\section{DENYING INCARCERATED INDIVIDUALS THE BENEFITS OF THE EARNED INCOME TAX CREDIT VIOLATES THE EQUAL PROTECTION ClAUSE}

In addition to the substantial policy considerations, the arbitrary distinction made between incarcerated taxpayers and other low-income taxpayers implicates the Equal Protection Clause. Under the Equal Protection Clause, people who are similarly situated should be treated the same by the law. ${ }^{87}$ Different levels of scrutiny are applied to a statute that potentially violates the Equal Protection Clause depending on the group that is impacted by the legislation and the rights that are implicated by the legislation. ${ }^{88}$ Classifications based on race and classifications that intrude upon a fundamental right are afforded strict scrutiny, classifications based on sex are

82 Children of Incarcerated Parents, NAT'L INST. OF CORRS., https://nicic.gov/children-ofincarcerated-parents (last visited Aug. 27, 2021).

${ }^{83}$ Eric Martin, Hidden Consequences: The Impact of Incarceration on Dependent Children, NAT'L INST. OF JUST. (Mar. 1, 2017), https://nij.ojp.gov/topics/articles/hidden-consequences-impactincarceration-dependent-children.

${ }^{84}$ I.R.C. § 32(b).

${ }^{85}$ Hasdell et al., supra note 17.

${ }^{86}$ Nichols \& Rothstein, supra note 18, at 8; CRANDALL-HOLLICK, supra note 20, at 4.

${ }^{87}$ Nordlinger v. Hahn, 505 U.S. 1, 10 (1992).

${ }^{88}$ See id.

Pitt Tax Review | ISSN 1932-1821 (print) 1932-1996 (online) DOI 10.5195/taxreview.2021.149 | http://taxreview.law.pitt.edu 
afforded intermediate scrutiny, and classifications that do not affect a suspect class or a fundamental right are afforded rational basis scrutiny. ${ }^{89}$

Under strict scrutiny, the classification drawn by the legislation at issue must "be narrowly tailored to serve a compelling state interest." 90 For legislation to survive review under the somewhat less exacting intermediate scrutiny, the distinction must "be substantially related to an important state interest." ${ }^{, 1}$ For a law to be upheld under rational basis review, the legislation must be rationally related to a legitimate state interest. ${ }^{92}$ Courts are generally deferential to the legislature when determining whether a law is related to a legitimate state interest under rational basis review. ${ }^{93}$ Courts have emphasized, however, that the legislation's means must actually fit the legislation's end goal, and "that a bare congressional desire to harm a politically unpopular group cannot constitute a legitimate government interest." 94

The Supreme Court has long held that while lawmakers are free to make their own decisions regarding taxation, tax statutes must comply with the Equal Protection Clause. ${ }^{95}$ While lawmakers generally have broad discretion when creating tax policy, "there is a point beyond which the State cannot go without violating the Equal Protection Clause."96 The Supreme Court has emphasized that statutes that deal with taxation must still withstand rational basis review "and may not resort to a classification that is palpably arbitrary." 97 Although the courts tend to defer to the legislature's determination of what classifications are reasonably related to the goals of (2014).

${ }^{89}$ See Susannah W. Pollvogt, Beyond Suspect Classifications, 16 U. PA. J. ConST. L. 739, 743-44

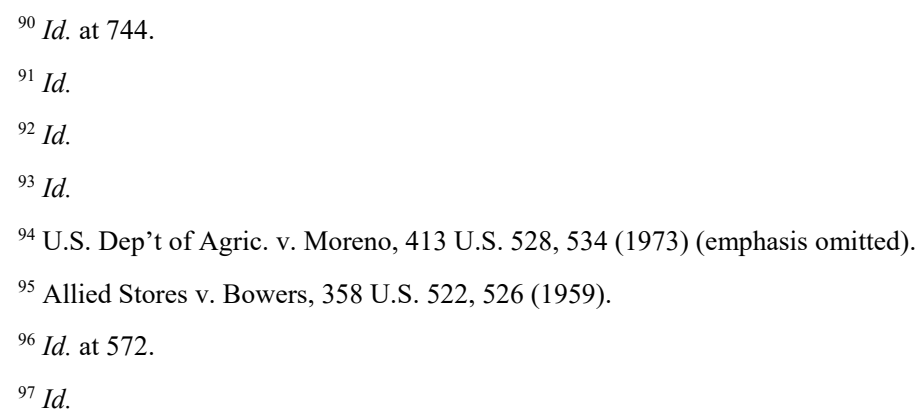

Pitt Tax Review | ISSN 1932-1821 (print) 1932-1996 (online) DOI 10.5195/taxreview.2021.149 | http://taxreview.law.pitt.edu 
the legislation, the Supreme Court has held that "the classification 'must rest upon some ground of difference having a fair and substantial relation to the object of the legislation." 98

Section 32(c)(2)(B)(iv) specifically differentiates between incarcerated individuals and other low-income taxpayers, ${ }^{99}$ and incarcerated individuals as a group are not considered a suspect class. However, while the classification made by $\S 32(\mathrm{c})(2)(\mathrm{B})(\mathrm{iv})$ does not implicate race directly, racial minorities are arrested and imprisoned at disproportionally high rates in the United States. ${ }^{100}$ Although only thirty-two percent of the U.S. population is Black or Latino, these two groups represent approximately fifty-six percent of the country's incarcerated population. ${ }^{101}$ This disparity becomes even more apparent when gender is taken into account, as "Black men are six times as likely to be incarcerated as white men and Latinos are 2.5 times as likely." 102 While $\S 32$ does not formally classify taxpayers based on race, in practice excluding incarcerated individuals from claiming the EITC treats many low-income White taxpayers differently than many lowincome taxpayers who are racial minorities. ${ }^{103}$ Because the classification arguably implicates a suspect class, the typical deference to Congress when it comes to tax legislation should not apply. Instead, courts should examine the distinction made between incarcerated taxpayers and other low-income taxpayers under a heightened form of scrutiny.

An Equal Protection Clause challenge has not been raised under the Federal Constitution regarding this EITC provision, so the government has

${ }^{98}$ Id. (citing F.S. Royster Guano Co. v. Virginia, 253 U.S. 412, 415 (1920); Louisville Gas \& Elec. Co. v. Coleman, 277 U.S. 32, 37 (1928); Air-Way Elec. Appliance Corp. v. Day, 266 U.S. 71, 85 (1924); Schlesinger v. Wisconsin, 270 U.S. 230, 240 (1926); Ohio Oil Co. v. Conway, 281 U.S. 146, 160 (1930)).

${ }^{99}$ I.R.C. $\S 32(\mathrm{c})(2)(B)(i v)$.

100 Michelle Alexander, The New Jim Crow: Mass InCarceration in the Age of COLORBLINDNESS 123 (2010).

${ }^{101}$ Criminal Justice Fact Sheet, NAACP, https://naacp.org/resources/criminal-justice-fact-sheet (last visited Aug. 28, 2021).

${ }^{102}$ Criminal Justice Facts, THE SENT'G PROJECT, https://www.sentencingproject.org/criminaljustice-facts/ (last visited July 20, 2021).

${ }^{103}$ In fact, "[t]he majority of low-income taxpayers eligible for the credit are white, and the majority of blacks can't receive the credit because they're ineligible." Dorothy A. Brown, Race and Class Matters in Tax Policy, 107 Colum. L. ReV. 790, 796 (2007).

Pitt Tax Review | ISSN 1932-1821 (print) 1932-1996 (online) DOI 10.5195/taxreview.2021.149 | http://taxreview.law.pitt.edu 
not needed to articulate a particular state interest that is being furthered by making a distinction between these two groups of similarly situated taxpayers. Based on the limited legislative history of $\S 32$ (c)(2)(B)(iv), the intention behind the distinction made between incarcerated and nonincarcerated low-income taxpayers is that incarcerated individuals do not need to be given a work incentive because they are already required to work while in prison. ${ }^{104}$ However, the EITC has evolved beyond its initial limited purpose as a work incentive, and the credit currently functions as one of largest antipoverty programs in the country. ${ }^{105}$ The EITC does not even serve as a work incentive for all taxpayers, and could actually disincentivize some married taxpayers from entering the workforce. ${ }^{106}$ While a court is less likely to apply strict scrutiny to this legislation as the classification does not implicate race directly, it is clear that $\S 32$ 's classification could not currently withstand this highest level of scrutiny. The classification in $\S 32$ does not serve a compelling state interest under strict scrutiny review, particularly at this point in the EITC's history. Section 32 is also not narrowly tailored, as it excludes even incarcerated taxpayers who are not compelled to work from claiming the EITC. ${ }^{107}$ Section 32's outdated exclusion of incarcerated individuals similarly fails to further an important state interest under intermediate scrutiny. Instead, the classification currently serves to exclude a group of low-income taxpayers, including a disproportionate number of taxpayers who are racial minorities, from accessing one of the largest antipoverty programs the federal government provides. ${ }^{108}$

Even under the most deferential rational basis level of review, the distinction $\S 32$ draws between incarcerated individuals and other lowincome taxpayers should not withstand an Equal Protection Challenge. When applying rational basis review to $\S 32$, the two relevant inquiries regarding

${ }^{104}$ Wilson v. Comm'r, 81 T.C.M. (CCH) 1745, 2001 T.C.M. (RIA) ๆ 2001-139 (2001).

${ }^{105}$ Earned Income Tax Credit \& Other Refundable Credits, supra note 64; EITC (Earned Income Tax Credit), supra note 64; see also STAFF OF H.R. COMM. ON THE BUDGET, supra note 64.

${ }^{106}$ Nichols \& Rothstein, supra note 18, at 19; see also What Is the Earned Income Tax Credit?, supra note 31 .

${ }^{107}$ Rogers v. Comm'r, 88 T.C.M. (CCH) 392, 2004 T.C.M. (RIA) $\mid$ 2004-245 (2004).

${ }^{108}$ Earned Income Tax Credit \& Other Refundable Credits, supra note 64; EITC (Earned Income Tax Credit), supra note 64; see also STAFF OF H.R. COMM. ON THE BUDGET, supra note 64.

Pitt Tax Review | ISSN 1932-1821 (print) 1932-1996 (online) DOI 10.5195/taxreview.2021.149 | http://taxreview.law.pitt.edu 
this portion of the statute are whether incarcerated individuals are being treated differently than other similarly situated taxpayers and whether the legislation reasonably furthers a legitimate government purpose. Incarcerated individuals as a group are in a somewhat unique situation because they do lose some rights that are fundamental to other citizens while they are incarcerated. Incarcerated individuals are the only people that the Thirteenth Amendment of the Constitution is thought not to apply to; ${ }^{109}$ are not eligible to exercise their fundamental right to vote while in prison; ${ }^{110}$ in many states, cannot even vote for years after their release from prison; ${ }^{111}$ and are among the only workers who do not have to be paid the federal minimum wage. ${ }^{112}$ While it is possible to argue that these differences make it so that incarcerated individuals cannot be similarly situated to other taxpayers, it is important to note that when it comes to the jobs that many of these individuals perform, there is not a significant difference between incarcerated workers and other low-income workers. Incarcerated individuals can work for many of the same types of organizations that employ other taxpayers, such as private businesses or nonprofit organizations. ${ }^{113}$ Some incarcerated individuals do not even work for these organizations at the prison itself, ${ }^{114}$ and while working they may not appear visibly distinct from nonincarcerated workers. Those who work while incarcerated are similarly situated to other lowincome taxpayers who work for the same types of organizations, but unlike those taxpayers, they are barred from claiming the Earned Income Tax Credit by $\S 32(\mathrm{c})(2)(\mathrm{B})(\mathrm{iv})$ of the Code. As a result, the distinction made between these different groups of low-income taxpayers is based solely on their

${ }^{109}$ Becky Little, Does an Exception Clause in the 13th Amendment Still Permit Slavery?, Hist. (Apr. 20, 2021), https://www.history.com/news/13th-amendment-slavery-loophole-jim-crow-prisons.

${ }^{110}$ See Felony Disenfranchisement Laws (Map), ACLU, https://www.aclu.org/issues/voting-rights/ voter-restoration/felony-disenfranchisement-laws-map (last visited Oct. 5, 2021).

${ }^{111}$ Chris Uggen et Al., The Sent'g Project, Locked Out 2020: Estimates of People Denied Voting Rights DUe to A FelONY CONVICTION 7 (2020), https://www.sentencingproject.org/wpcontent/uploads/2020/10/Locked-Out-2020.pdf.

${ }^{112}$ See Bennett v. Frank, 395 F.3d 409, 409-10 (7th Cir. 2005); see also Danneskjold v. Hausrath, 82 F.3d 37, 39 (2d Cir. 1996).

${ }^{113}$ Sawyer, supra note 3.

${ }^{114}$ Id.

Pitt Tax Review | ISSN 1932-1821 (print) 1932-1996 (online)

DOI 10.5195/taxreview.2021.149 | http://taxreview.law.pitt.edu 
incarceration status, raising a potential violation of the Equal Protection Clause.

While great deference has been given to lawmakers when it comes to making distinctions in the tax laws, the Supreme Court has held that the relationship between the classification and the goal of the legislation cannot be "so attenuated as to render the distinction arbitrary or irrational." 115 The distinction between incarcerated individuals and other low-income taxpayers may have rationally furthered a legitimate government purpose when the statute was first enacted, but as the credit has grown and evolved to become an antipoverty program rather than a work incentive, ${ }^{116}$ the arbitrary distinction between these groups can no longer be understood to rationally further a legitimate state interest.

\section{CONCLUSION}

Section 32(c)(2)(B)(iv) of the Code should be amended to allow incarcerated individuals to claim the Earned Income Tax Credit. While the credit does not need to function as a work incentive in a setting where labor is mandatory, the EITC has expanded over the years to become one of the most significant antipoverty programs in the United States. ${ }^{117}$ The EITC has outgrown its initial purpose and become an integral part of the fight against poverty, and this change should be reflected by amending the credit to cover all of our most impoverished citizens. In addition to these significant policy considerations, the classification made by $\S 32$ arguably violates the Equal Protection Clause. While incarcerated individuals as a group are not considered a suspect class, the disproportionate number of racial minorities in U.S. prisons should require courts to closely examine the distinction $\S 32$ makes between low-income taxpayers. Under a heightened level of scrutiny, the rationale for incarcerated individuals' exclusion from claiming the EITC should not be seen as furthering a compelling or important state interest. Even under a more deferential level of review, legislation that treats incarcerated individuals differently than other low-income individuals treats similarly

\footnotetext{
${ }^{115}$ Nordlinger v. Hahn, 505 U.S. 1, 11 (1992).

${ }^{116}$ Earned Income Tax Credit \& Other Refundable Credits, supra note 64; EITC (Earned Income Tax Credit), supra note 64; see also STAFF OF H.R. COMM. ON THE BUDGET, supra note 64.

${ }^{117} I d$.
}

Pitt Tax Review | ISSN 1932-1821 (print) 1932-1996 (online) DOI 10.5195/taxreview.2021.149 | http://taxreview.law.pitt.edu 


\section{$100 \mid$ Pittsburgh Tax Review | Vol. 192021}

situated wage earners differently for an arbitrary reason that is not rationally related to a legitimate government purpose. Lawmakers should amend this arguably unconstitutional provision of the Code to allow incarcerated individuals to receive the same tax treatment as other low-income workers.

Pitt Tax Review | ISSN 1932-1821 (print) 1932-1996 (online) DOI 10.5195/taxreview.2021.149 | http://taxreview.law.pitt.edu 